\title{
MENDALAMI DOKTRIN TRINITAS DALAM PANDANGAN HANS URS VON BALTHASAR
}

\author{
M arkus Situmorang \\ STFT Widya Sasana M alang
}

\begin{abstract}
A bstract
All the Hans Urs von Balthasar theology is the Trinity. For him everything flows from interpersonal relationships in the Trinity. The starting point for understanding the Trinity must depart from the event of love. Jesus is a manifestation of God's love that appears to humans. God's love is beautiful. Jesus revealed the beauty of the Triune God. The fundamental aspect of beauty is obedience from Jesus. Jesus as the beauty that manifest the Father and the Holy Spirit. We will not be able to understand the beauty of Christ without referring to inter-Trinitarian beauty. It does not stop at mere beauty but God is involved in the history of human life. In other words, God is involved in drama with humans. On the Good Friday, there was a drama between God and the world on the cross. But a more dramatic drama took place on Holy Saturday. Drama also occurs in the life of the Trinity. The three divine persons empty themselves which are united in a bond of love. The real kenosis occurs in a triunelife. The Trinity lives in the Church and maintains the Church. The church's teachings are undeniable because of the truth of the Trinity itself.
\end{abstract}

Keywords: Trinity, love, beauty, drama, inter-Trinity, kenosis, Good Friday, Holy Saturday, Church, truth.

\begin{abstract}
A bstraksi
Seluruh teologi Hans Urs von Balthasar adalah Tritunggal. Baginya segala sesuatu mengalir dari relasi antar pribadi dalam Tritunggal. Titik tolak untuk memahami Tritunggal harus berangkat dari peristiwa kasih. Yesus adalah wujud kasih Allah yang tampak kepada manusia. Kasih Allah sendiri sangat indah. Yesus mewahyukan keindahan dari Allah Tritunggal. Aspek fundamental dari keindahan itu yakni ketaatan dari Yesus. Yesus sebagai keindahan yang mewahyukan Bapa dan Roh Kudus. Wujud dari Yesus mengacu kepada wujud dari Allah dal am diri-Nya sendiri.Trinitas seperti cinta di dalam dirinya sendiri. Kita tidak akan dapat memahami keindahan Kristus tanpa mengacu pada keindahan inter-Trinitaris. Tidak berhenti pada keindahan semata tetapi Allah terlibat di dalam sejarah kehidupan manusia. Dengan kata lain Allah terlibat drama dengan manusia. Pada peristiwa Jumat Agung terjadi drama antara Allah dan dunia di kayu salib. Namun drama yang lebih dramatis
\end{abstract}


terjadi pada Sabtu Suci. Drama juga terjadi juga di dalam kehidupan Tritunggal. Tiga pribadi ilahi saling mengosongkan diri yang disatukan dalam ikatan cinta. Tritunggal itu yang hidup di dalam Gereja dan memelihara Gereja. Ajaran-ajaran Gereja tidak terbantahkan karena kebenaran Tritunggal itu sendiri.

Kata-kata kunci: Trinitas, cinta, keindahan, drama, inter-Tritunggal, kenosis, Jumat Agung, Sabtu Suci, Gereja, kebenaran.

\section{Pengantar}

Hans Urs von Balthasar adalah seorang imam dan teolog katolik. Ia dilahirkan di Lucerne, Swiss, 12 Agustus 1905 dan meninggal 26 Juni 1988. Pendidikan dasar ditempuhnya di lembaga Yesuit Stella Matutina, Feldkirch, Austria. Kemudian ia melanjutkan pendidikan di Wina, Berlin dan Zurrich. Pada tahun 1929 ia bergabung dengan Jesuit. Tujuh tahun kemudian (1936) dia ditahbiskan menjadi imam. Hans Urs von Balthasar merupakan salah satu teolog yang berpengaruh pada abad XX. Karya-karyanya yang terkenal antara lain: The Glory of the Lord (7 jilid); Theo-D rama: Theological D ramatic Theory (5 jilid); Theo-Logic (3 jilid). Sumber teologi Tritunggal dalam karya-karyanya secara khusus berakar pada tradisi patristik (Ireneus, Origenes, Gregorius Nissa dan Maximus confessor) dan dari abad pertengahan (Riccardo di San Vittore dan Thomas Aquinas).

Hans Urs von Balthasar memiliki cara berpikir melingkar. Kita dapat menemukan doktrin yang sangat menarik dan luar biasa yang memperkaya ajaran kristiani. Pada kenyataannya doktrin Trinitas Balthasar adalah suatu benang merah. Kita tidak memiliki buku Balthasar yang membahas secara khusus tentang Trinitas. Namun seluruh teologinya adalah Tritunggal. Dalam setiap bukunya kita dapat menemukan sesuatu yang baru tentang Trinitas. Dari mana kita berangkat untuk memulainya? Berbicara teologi Hans Urs von Balthasar tentang Tritunggal harus bertitik tolak dari peristiwa kasih.

\section{Tuhan mengasihi manusia}

Balthasar bertanya apa esensi dari kekristenan. Ada sekian banyak kebenaran iman dalam ajaran kristen. Dalam pluralitas kebenaran kristen tersebut kita perlu memiliki titik temu dari semuanya. Balthasar mengatakan bahwa dalam patristik, abad pertengahan dan renaissans titik temu telah ditempatkan pada taraf kosmik atau dunia secara 
keseluruhan. Pendekatan demikian membuat kekristenan mengambil karakter penyempurnaan. Semua konsep kosmologi menemukan kepenuhan dan pondasinya dalam Firman yang telah menjadi manusia. Kekristenan adalah prinsip pemersatu dari elemen parsial dari kebajikan kuno. Bapa-bapa Gereja ingin menunjukkan bahwa mereka telah mengasumsikan kebajikan kuno, tetapi dalam Kristus kebajikan parsial ini menemukan pemenuhannya.

Era modern telah beralih kepada manusia (antropologis) dan mengembangkan kekristenan sebagai pemenuhan pribadi manusia. Manusia dilihat tidak hanya sebagai mikrokosmos (dunia kecil) tetapi juga sebagai penafsir segala sesuatu dengan akal budinya yang melampaui dan mengatasi alam. Pendekatan ini menemukan klimaksnya pada Kant. Gagasan-gagasan Iain dalam Kant melampaui batas-batas dari pengalaman inderawi dan kategori-kategori intelek yang dipahami dalam kerangka moralitas. Beberapa teolog seperti Karl Rahner telah menggunakan pendekatan transendental mulai dari refleksi kesadaran diri dari subjek manusia dan pertanyaan kondisi transendental dari kemungkinan auto-komunikasi Tuhan kepada manusia.

Von Balthasar mengatakan bahwa esensi dari agama kristen hanya dapat ditemukan pada taraf cinta karena Allah Tritunggal yang telah menyatakan diri-N ya kepada kita dalam Yesus adalah Cinta. Di sini peristiwa cinta sebagai jalan ketiga yang berbeda dari jalan kosmologis dan antropologis. Bal thasar mengatakan bahwa tidak mungkin berangkat dari kosmos atau dari manusia ketika Allah menyatakan diri-N ya sebagai Cinta dalam sebuah drama. Pendekatan kosmologis bertitik tolak dari segala sesuatu. Sementara pendekatan antropologis tidak berbicara tentang segala sesuatu, tetapi berpusat pada manusia sebagai individu. Gagasan Balthasar yaitu ketika berbicara tentang peristiwa cinta, ada pribadi lain yang mengatakan "A ku mencintaimu" dan pribadi ini adalah Allah, sutradara dan penulis dari segala sesuatu.Kita melihat ada tiga pendekatan. Balthasar mengatakan bahwa sebuah cinta yang diberikan kepadaku selalu dapat saya pahami dan semata-mata seperti sebuah keajai ban dan"saya" tidak bisa memanipulasinya. "Saya" dapat memanipulasi seseorang tetapi ketika"saya" berbicara tentang cinta tidak mungkin memanipulasinya karena cinta datang sebagai anugerah dan sebuah kejutan. Balthasar menempatkan pada tempat yang pertama keagungan cinta yang mengambil rupa tubuh di dalam Yesus. Perjumpaan dengan cinta yang demikian sangat penting bagi seorang kristen dan melampaui pendekatan-pendekatan kita. Balthasar menjelaskan seperti peristiwa kelahiran seorang anak demikian juga pengalaman cinta itu sendiri.

Ketika seorang ibu tersenyum kepada anaknya selama berhari-hari dan berminggu-minggu, tiba saatnya sang anak membalas dengan senyuman. Ia 
telah membangkitkan cinta di hati sang anak dan sang anak bangkit untuk mencintai, muncul kesadaran[...]. Pengenalan (dengan semua perangkat intuisi dan konsepnya) mulai bekerja karena cinta telah digerakkan oleh sang ibu (atau masing-masing oleh prinsip transenden). Dengan demikian Tuhan yang mewahyukan diri kepada manusia sebagai kasih adalah Tuhan yang menerangi cinta dan membuatnya bersinar dan menerangi hati manusia, cahaya itu yangmenampakkan cinta ini-cinta yang mutlak: "Sebab Tuhan telah berfirman: "Dari dalam gelap akan terbit terang!", la juga yang membuat terang-N ya bercahaya di dalam hati kita, supaya kita beroleh terang dari pengetahuan tentang kemuliaan Allah yang nampak pada wajah Kristus" (2 Kor 4:6). Wajah itu penyebab pertama seorang bapa dan ibu tersenyum kepada kita. Karena kita adalah ciptaan-Nya, benih dari kasih - sebagai gambaran (imago) Allah - tidak aktif di dalam kita. Akan tetapi tidak ada anak yang terbangun untuk mencintai jika ia tidak dicintai, dengan demikian tidak ada hati manusia yang dapat membangkitkan pemahaman akan Tuhan tanpa pemberian yang cuma-cuma dari rahmat-Nya - dalam gambar putra-Nya. ${ }^{1}$

Kutipan yang indah dan terkenal yang sering dikutip oleh Balthasar. A pa fenomena yang pertama atau yang mendasar dari realitas? Seseorang mungkin akan mengatakan bahwa metafisika tidak ada dan apa yang penting adalah pengalaman inderawi yang membuat seseorang melihat dan menyentuh. Yang lain mungkin mengatakan bahwa fenomena mendasar adalah hukum-hukum matematika yang tetap. Balthasar mengatakan bahwa fenomena pertama adalah pengalaman cinta. Tanpa cinta,sampai kapanpun seseorang tidak akan mampu berpikir secara logis. Pengalaman manusia yang mendasar adalah ada yang Iain "Engkau" yang mengatakan, "A ku mencintaimu", di dalamnya seorang anak kecil bertumbuh dan memiliki kesadaran akan dirinya (aku). Seorang anak pertama kali menemukan cinta dari seorang ibu. Kemudiansang anak menemukan bahwa cinta sang ibu berakhir, tetapi pengalaman ini tinggal tetap dan kemudian cinta terarah kepada yang religius, kepada cinta yangtak terbatas. Realitas ini yang kita sebut Tuhan.

Kita dapat menganalogikan antara cinta orangtua dan Tuhan yang muncul di dalam diri kita. Cinta ini tidak bisa didapatkan dari luar cinta, yang bukan kekuatannya. Semua itu hanya dapat diberikan dan digenapi dalam Yesus. Cinta sejati tak terduga dan oleh karena itu cuma-cuma. Balthasar suka mengutip kata-kata prefasi Natal: "dalam misteri Sabda yang menjelma telah tampak oleh matahati kita, cahaya di dalam kemegahan-N ya ...".Kecemerlangan dari keindahan cinta Allah yang tidak terbatas tidak akan mampu menginspirasi cintajika la tidak memiliki rupa yang kelihatan di dalam Kristus. Allah yang tidak kelihatan memanifestasikan diri-Nya dengan cara yang kelihatan kepada kita.Wahyu ini adalah kebaruan yang absolut yang tidak dapat ditutup

1 H.U. von Balthasar, Solo l'amore è credibile. Roma: Queriniana, 2001, p. 7. 
dalam sistem kosmologis. Cinta Allah diberikan di dalam Kristus tidak perlu diberikan alasan dan penjelasan karena cinta jelas dalam dirinya sendiri. Tidak perlu banyak penjelasan kosmologis dan antropologis, karena dapat dilihat dengan jelas seperti senyuman dari seorang ibu. Cinta bukan bagian dari sistem melainkan dasar dari sistem apapun. $\mathrm{M}$. Gallagher mengatakan bahwadi situlah terletak inti polemik antara Balthasar dan Rahner. Rahner tidak hadir dengan bahasa iman yang eksplisit sementara Balthasar ingin memulai dari Kristus yang datang dan menunjukkan bahwa semua individu merupakan wajah cinta. ${ }^{2}$

\section{Keindahan dari Allah: estetika teologis}

Berbicara tentang wahyu dalam Yesus, Balthasar mengembangkan estetika teologis. Bagian pertama dari teologinya diberi judul "Gloria". Balthasar tidak menyangkal apologetik dari tanda-tanda, tetapi menggunakan apologetik dari bentukberkaitan dengan pemahaman tokoh sejarah yaitu sang Putra yang meletakkan dasar suatu keindahan yang secara harfiah mempesonakan.Semuanya termanifestasi di dalam Kritus. Yesus mempesonakan dan memikat kita. Balthasar berbicara tentang keindahan dari cinta. Cinta adalah indah. Balthasar menjadikan pengalaman cinta ini sebuah bentuk pengenalan akan Allah yang mewahyukan diri dalam sejarah Yesus. Von Balthasar mengacu pada injil Yohanes: "Firman itu telah menjadi manusia, dan diam di antara kita, dan kita telah melihat kemuliaan-Nya, yaitu kemuliaan yang diberikan kepada-Nya sebagai anak tunggal Bapa, penuh kasih karunia dan kebenaran" (Yoh 1:14).

Kita melihat bahwa estetika teologis dari Balthasar bukanlah pendekatan dari suatu kemuliaan sebagaimana yang dipahami ol eh dunia tetapi keberadaan keindahan yang diwahyukan secara paradoks dalam kisah-kisah tragis di kayu salib. Von Balthasar berbicara tentang estetika teologis yaitu tentang keindahan dari Allah. Dimensi estetik ini sedikit banyak telah hilang atau diabaikan dalam teologi dan juga dalam pewartaan meskipun selalu ada seni yang indah di dalam Gereja yakni seni religius. Dapat dikatakan bahwa salah satu gejala dari krisis Gereja saat ini adalah kurangnya seni religius. Seni dipisahkan dari pengalaman religius. Seni saat sekarang inisedikit kasar, harus memprovokasi.Gereja membutuhkan para seniman keindahan. Liturgi tidak hanya soal pertanyaan dari sebuah kebenaran tetapi juga keindahan. Berbicara tentang kebenaran dari dogma dan kebaikan, apa yang baik dan yang jahat (soal moral)terkadang telah kehilangan keindahannya. Kebenaran,

2 Michael P. Gallagher, M appe della fede. D ieci grandi esploratori cristiani. Milano: V\&P, 2011, p. 70. 
kebaikan dan keindahan merupakan tiga unsur transendental dari teologi abad pertengahan. Yang transendental adalah yang universal, ada yang dapat berubah, mereka merupakan milik dari sang Ada. Kita memiliki tiga titik tolak untukberteologi. Kita dapat berbicara tentang Allah dari kebaikan, kebenaran dan keindahan. Pada umumnya kita harus menggabungkan tiga poin awal ini. Dalam Alkitab, "Gloria” adalah suatu konsep kunci yang membangkitkan momen epiphany dari kebesaran Allah. Kemuliaan ini merupakan konsep penting dalam alkitab.

Keindahan ini telah mencapai puncaknya dalam pribadi Yesus yakni dalam misteri Paskah,saat kematian dan kebangkitan-Nya. Kita bisa melihat keindahan Yesus di dalam kematian dan kebangkitan- $\mathrm{N}$ ya. Mengutip kata-kata rasul Paulus: "Jika Injil yang kami beritakan masih tertutup juga, maka ia tertutup untuk mereka yang akan binasa, yaitu orang-orang yang tidak percaya, yang pikirannya telah dibutakan oleh ilah zaman ini sehingga mereka tidak melihat cahaya injil tentang kemuliaan Kristus yang adalah gambaran A llah. Sebab bukan diri kami yang kami beritakan, tetapi Yesus Kristus sebagai Tuhan dan diri kami sebagai hambamu karena kehendak Yesus. Sebab Allah yang telah berfirman: “Dari dalam gelap akan terbit terang!" (2 Kor 4:3-6). Ia juga yang membuat terang-Nya bercahaya di dalam hati kita supaya kita beroleh terang dari pengetahuan tentang kemuliaan Allah yang nampak pada wajah Kristus.Estetika yang diungkapkan oleh rasul Paulus. Wujud dari Yesus mengacu kepada wujud dari Allah dalam diri-N ya sendiri (Trinitas seperti cinta di dalam dirinya sendiri). Kita tidak akan dapat memahami keindahan Kristus tanpa mengacu pada keindahan inter-Trinitaris.

Bagi Balthasar aspek mendasar dari keindahan Kristus adalah ketaatan-Nya kepada Bapa. Ini merupakan salah satu dari konsep yang utama. Kodrat Yesus adalah ketaatan kepada Bapa. Hal itu mengacu pada beberapa kutipan dari Yohanes:"...makanan-Kuialah melakukan kehendak Dia yang mengutus dan menyelesaikan pekerjaan-Nya" (Yoh 4:34)."Sebab Aku telah turun dari sorga bukan untuk melakukan kehendak-Ku, tetapi untuk melakukan kehendak Dia yang telah mengutus Aku" (Yoh 6:38). Dalam misi ketaatan Yesus ini hadir Roh Kudus yang mewahyukan kepada Yesus kehendak Bapa.Roh Kudus turun ke atas Maria dan kemudian Putra dikandung. Dalam Lukas kita baca bahwa sang "anak" tumbuh dan menjadi kuat dalam roh dan dalam pembaptisan turun Roh Kudus dalam bentuk jasmaniah (Luk 3:22). Yesus menjauh dari sungai Yordan, lalu dibawa oleh Roh ke padang gurun. Roh Kudus mewahyukan kepada Yesus kehendak Bapa-Nya. Balthasar menul is bahwa Roh Allah yang kepada-N ya Yesus taat, mengekspresikan kehendak Bapa di dalam Dia. Misteri penugasan dari Putra di dunia adalah misteri Trinitaris. Taat kepada Bapa dan dibimbing ol eh Roh. Yesus adalah keindahan yang tampak yang mengungkapkan Bapa dalam Roh 
Kudus. A kan tetapi pewahyuan juga merupakan sebuah drama.Dari sang Keindahan,kita menuju kebaikan yang direalisasikan.

\section{D rama Tritunggal}

Von Balthasar menjelaskan bahwa keindahan berada pada tingkat cahaya, gambaran dan visi yang merupakan satu dari dimensi teologi. Tindakan berikutnya adalah peristiwa, aksi dan drama. Allah berkarya dalam kaitannya dengan manusia dan manusia menanggapi. Drama ini bukanlah tragedi, tetapi tindakan yang berkembang. Gallagher mengatakan bahwa iman melampaui kedamaian yang menenangkan dan menjadi sebuah gerakan, tidak bisa hanya kontemplasi dari keindahan itu, tetapi juga sebuah drama atau pertempuran. Dalam Perjanjian Lama terlebih dal am Islam dan deisme, Allah berada di atas drama. Allah adalah jauh. Dalam mitologi klasik para dewa terlibat dalam sejarah manusia yang terlebur di dalamnya. Dalam kekristenan drama ilahi dari dunia diwahyukan secara berbeda.

“Tuhan dalam diri-Nya sendiri adalah kehidupan, kasih, pertukaran abadi di dalam kepenuhan, sehingga menciptakan dunia, bertindak benar-benar dengan bebas [...]. Dia dapat menyerahkan diri-Nya kepada dunia dan akan berkomitmen, tetapi tanpa kehilangan diri-N ya. Drama yang terbentang di hadapannya, dengan mana la bebas bersentuhan, bukanlah prosesnya sendiri [...] di tempat kedua, Allah Tritunggal - sebagaimana kita ketahui dari iman kita dalam pewahyuan - dapat memasukkan seluruh kebenaran dalam dunia melalui peristiwa dimana Putra Allah "menjadi sama dengan kita dalam segala hal kecuali dalam hal dosa". Dia benar-benar bertindak bersama kita di hadapan Bapa dan melalui Roh Kudus."3

Allah yang begitu terlibat dalam sejarah yang menjadi proses ilahi untuk menjadi Tuhan dalam kepenuhan-Nya. Allah benar-benar berkomitmen turun ke dunia tanpa hilang di dalamnya seperti dalam mitologi kuno. Penting untuk memahami apa yang terjadi dalam Teodrama ini. Dalam Yesus, misi bersamaan dengan pribadi secara ontologis. Pribadi Yesus adalah misi-Nya. Misi adalah seluruh pribadiNya. Yesus tidak melakukan teater tetapi misi-Nya adalah kepribadianNya. Misi adalah kehendak Bapa dan ketaatan ini membentuk kepribadian Yesus.

\subsection{Misteri Jumat Agung}

Drama antara Allah dan dunia terjadi di kayu salib. Yesus mati di kayu salib dan ditinggalkan oleh Bapa-Nya. Perlu digarisbawahi bahwa

3 H.U. Von Balthasar, Teodrammatica. III. Le persone del dramma. L'uomo in Cristo. Milano: Jaca Book, 1983, p. 487. 
peristiwa salib dipikirkan hanya dalam perspektif Trinitaris. Salib mewahyukan puncak dari kehidupan Tritunggal. Pada salib ada jarak yang begitu mendalam antara Bapa dan Putera. Roh Kudus mengisi jarak ini. Cinta menyatukan dan bukan menghancurkan yang lain. Keberjarakan dan kedekatan dalam cinta terjadi bersamaan. Lebih jauh (berjarak) dan lebih dekat. Jika Allah pribadi tunggal tidak akan dapat melakukan peristiwa sebagaimana salib Yesus. Dalam misteri paskah ditunjukkan hubungan yang dramatis antara Bapa dan Putera seperti yang kita baca di dalam surat Paulus. "Dia yang tidak mengenal dosa, telah dibuat-Nya menjadi dosa karena kita, supaya dalam Dia kita dibenarkan oleh Allah" (2Kor 5:21). Dari kenosis ini Bapa membangkitkan Putra kepada kemuliaan yang tak terbatas (Kis 13:33).

Drama ini dramatis tetapi tidak tragis. Kurban dan kemuliaan serta keindahan terjadi bersama-sama. Peristiwa salib dapat dikatakan pertama-tama merupakan peristiwa antara Allah dan Allah. Dalam hal apa peristiwa itu dianggap sebagai peristiwa antara Allah dan Allah? Kita melihat di satu sisi ada jurang yang dalam (neraka) di dalam kehidupan ilahi. Yesus ingin piala diambil tetapi tampaknya tidak mendapatkan jawaban. Yesus ditangkap, dihukum dan disalibkan. "Allahku, ya Allahku, mengapa Engkau meninggalkan Aku?" (Mzm 22).Ada jarak antara Bapa dan Putra. Paulus mengatakan dal am suratnya bahwa Allah tidak menyayangkan Putra-N ya yang tunggal. Yesus mengalami ditinggalkan seperti orang berdosa dalam kondisi terhukum (Rm 8:32).

Dapat dikatakan bahwa oleh karena itu neraka mungkin (Rahner mengatakan bahwa neraka sebenarnya merupakan realitas Kristologis, neraka jika ada tidak berada di luar Allah bukan realitas yang sesungguhnya karena Allah adalah segalanya - jika Tuhan tidak dapat mengalami, bertahan hidup dalam kondisi kutukan dari neraka, keberadaan neraka kekal tidak akan mungkin, tetapi Yesus mengalami neraka dapat dilihat sebagai realitas Kristologi dan ada. Mungkin ada seorang pendosa yang berkata kepada Allah bahwa tidak ingin bersama Allah dan orang berdosa ini tidak dihancurkan, tetapi hidup meskipun tidak dalam persatuan dengan Allah).Drama yang terjadi antara Allah dan dunia menemukan puncaknya padakayu salib. Kita dapat mengatakan bahwa puncak dari segala puncak ditemukan di dalam teriakan Yesus: "Allah ku, ya Allahku mengapa Engkau meninggalkan Aku?" (Mat 27:46). Kalimat ini adalah ekspresi dramatis dari kejauhan, keterpisahan antara Bapa dan Putra. Yesus mengalami keadaan ditinggalkan secara mendalam seperti orang berdosa dan yang dikutuk. Yesus mengalami situasi ini sebagai yang terhukum di atas salib. Akan tetapi pengalaman yang lebih lagi terjadi dalam keheningan pada Sabtu Suci. 


\subsection{Misteri Sabtu Suci}

Tema yang terkenal dari Balthasar adalah teologi Sabtu Suci. Di dalam teologi ini dibicarakan misteri Jumat Agung dan kebangkitan. Hal yang paling inovatif dari teologi tri hari suci adalah teologi Sabtu Suci. Balthasar menggemakan kembali gambaran Kitab Suci sebagaimana diungkapkan dalam surat pertama rasul Petrus saat Yesus turun ke neraka. "Dan di dalam Roh itu juga la pergi memberitakan injil kepada roh-roh yang di dalam penjara (bdk. 1 Ptr 3:19); “Itulah sebabnya maka Injil telah diberitakan juga kepada orang-orang mati, supaya mereka, sama seperti semua manusia, dihakimi secara badani; tetapi oleh roh dapat hidup menurut kehendak Allah (1 Ptr 4:6). Balthasar lebih suka melihat perjalanan ini sebagai sebuah simbol pemberian diri yang total dari Kristus dengan pendosa. Bagi Balthasar, Sabtu Suci mewakili identifikasi yang total dari Yesus dengan manusia.Dia menjelaskan gambaran ini dengan mengacu kepada Perjanjiana Lama yakni situasi Sheol. ${ }^{4}$ Penderitaan Yesus tidak berakhir dengan kematian di salib. Sang Putera turun ke dalam neraka yakni mengalami neraka. Bagi Balthasar,peristiwa turunnya ke dalam neraka ini termasuk dalam pengalaman dari neraka. Balthasar memahami turunnya ini bukan sebagai kemenangan (sebagian besar dari tradisi kristen berbicara tentang kemenangan Yesus atas kematian), tetapi sebagai suatu sikap menyerahkan diri hingga akhir sebagaimana nasib seorang yang dikutuk.Yesus solider dengan orang berdosa. Di neraka la mengalami penolakan yang sepenuhnya dari Bapa. Semua dosa manusia ditimpakan kepada-Nya. Di sini tampaknya ada "keretakan" relasi antara Bapa dan Putera. Namun Roh Kudus merangkul yang tak terbatas ini dan dengan demikian dosa itu sendiri ditutupi di dalam cinta ilahi.

Di kayu salibYesus mati disalibkan, tetapi Ia lebih bersimpati dengan yang terhukum dalam misteri Sabtu Suci karena mengalami neraka. Pada Jumat Suci kita hayati sebagai puncak dari kenosis. A kan tetapi Sabtu Suci lebih kenotis. Pada Jumat Agung kita berhadapan dengan penderitaan aktif dari Yesus. Yesus menderita dan mati. Namun dari salibla masih berbicara. la aktif meskipun tangan dan kaki-Nya dipaku. Bahkan saat menjelang kematian, AnakManusia masih aktif karena dapat mengampuni. Dalam misteri Sabtu Suci terdapat sikap pasif yang radikal dari penderitaan dan kematian Yesus. Saat turun ke dalam neraka, Yesus tidak dapat melakukan apa-apa, akan tetapi tidak melakukan apa-apa

4 Sheol merupakan situasi kematian. Berbagai metafora dilukiskan oleh pemazmur untuk menggambarkannya: tempat kegelapan (M zm 49:19); tempat sunyi (Mzm 94:17); suatu tempat yang darinya orang tidak akan kembali (Ayb 7:9); digambarkan seperti lobang kubur dan penjara abadi (bdk. Mzm 30:10; Mzm 85:6); di situ orang-orang yang sudah meninggal terkurung, terasing dari Tuhan dan dunia, tanpa kekuatan dan semangat, mereka hanya debu (bdk. Mzm 30:9). 
justru melakukan sangat banyak. Ini adalah teologi Sabtu Suci. O’Donnell merangkum:

“Bagi Balthasar Sabtu suci merepresentasikan identifikasi total Yesus dengan manusia dalam kesadaran-Nya. Sebagaimana mengidentifikasikan dengan kondisi orang berdosa, Yesus mati, tidak berdaya, terpisah dari Bapa, tidak dapat menebus diri-Nya sendiri. Dengan demikian Yesus mengidentifikasikan diri-Nya sebagai yang ditinggalkanoleh Allah, sebagaimana dikatakan oleh Paulusyang telah melakukan dosa. Dengan demikian Ia mengalami ketidakmampuan radikal dan dalam keadaan terlupakan sebagai seorang pendosa. [...].Kristus mati untuk orang berdosa dan mengambil tempatnya di neraka. [...] Dia membiarkan manusia bebas untuk memilih keterasingan yang radikal dan kesepian. Akan tetapi melalui salib, Tuhan datang dengan cinta untuk mengganggu kesendirian orang berdosa. Tuhan tidak melanggar kebebasan orang berdosa, tetapi kehadiran Allah bersama dengan orang berdosa mengganggu kesendiriannya. Orang berdosa tentunya menemukan dirinya di neraka tetapi tidak lagi sendirian." ${ }^{5}$

Allah mencari orang berdosa, melakukan segala sesuatu untuk menyelamatkan orang berdosamengikuti hingga sampai dekat neraka. Dia telah mengganggu kesepian/ kesendirian dari pendosa dengan kesepian-Nya sendiri. A spek kesendirian dari keheningan Yesus dinyatakan dalam ritus liturgi Paskah.Yesus yang mengosongkan diri secara maksimal dan hadir di antara para pendosa yang dihukum. Dengan cara ini, von Balthasar berpindah dari antara orang-orang terhukum (menekankan keadilan Allah-kepastian yang dihukum dalam neraka) dan ide apokatastasi yang mengungkapkan rekonsiliasi yang universal dan menekankan kemurahan Tuhan. Dalam ketegangan ini, berangkat dari teologi Sabtu Suci, Balthasar mempertahankan keharusan berharap untuk semua. Seseorang dapat memiliki harapan untuk semua bahwa Allah akan berhasil mencapai kesendirianorang hukuman darisetiap pendosa. Akan tetapi Balthasar berbicara tentang keharusan berharap untuk semua orang agar berdoa bagi semua tanpa menyangkal kemungkinan dari hukuman yang tidak dapat dibatalkan.Kita dapat berbicara tentang pengembangan dari teologi harapan Balthasarian, yaitu didasarkan di bawah rangkulan (pelukan dari bawah) kasih Allah Tritunggal dalam salib Kristus dan kasih Allah yang mengambil dosa dari manusia dari bawah. Hal ini berarti bahwa Kristus menderita ditinggalkan oleh Allah, yangselayaknya diterima oleh pendosa dalam ketaatan yang ekstrim yang tidak hanya membawa-N ya pada salib tetapi turun ke neraka.Kejahatan menemukan akhirnya di dalam cinta yang merangkulnya. Allah lewat karya Yesus merangkul dosa. Pendosa ada di antara Tritunggal. Jika dosa dapat dirangkul berarti bahwa hal itu dapat dihancurkan dan orang berdosa bisa diselamatkan.

5 J. O'Donnell, Tutto l'essere è amore, in: Hans U rs von Balthasar. Figura e opera. a cura di- K. Lehmann e W. Kasper, Casale Monferrato, 1991, pp. 343. 


\subsection{D rama antar Ilahi}

Balthasarmenekankan bahwa sejarah keselamatan dari Yesus terutama misteri Paskah,dari salib turun ke dalam neraka mengingatkan kita pada kehidupan Allah dalam diri-N ya sendiri. Berangkat dari situasi Trinitas ekonomi turun ke dalam neraka, kita dapat mengatakan sesuatu tentang hubungan antar Ilahi. Dalam misteri Paskah Yesus, pribadi dan misi-Nya berakar dalam hubungan yang kekal dalam inter-Trinitaris. Drama ekonomi ini dimungkinkan karena akarnya ditemukan dalamdrama inter-Trinitaris. Drama ini kita ketahui dari sejarah yang berpuncakpada salib Yesus yang mungkin karena kita berhadapan dengan drama antar-Ilahi yakni antara Bapa, Putra dan Roh Kudus. Salib mewahyukan kepada kita drama inter-Trinitaris ini. Von Balthasar tidak ingin berbicara seperti Rahner dari identitas sempurna antara Trinitas imanen dan Trinitas ekonomi. Ia mengatakan bahwa drama ini didasarkan pada inter-Trinitaris ini.Balthasar menafsirkan bahwa drama sang Putra pada sisi yang mengiringi dalam turunan (generasi)pada Tritunggal imanen. Hembusan Roh Kudus atasGereja merupakan kenyataan yang diberikan kepada Gereja. Balthasar melihatnya sebagai prosesi Trinitas ekonomi melalui hembusan. Trinitas ekonomi muncul sebagai terjemahan dari Trinitas imanen yang didasarkan dari yang pertama, tetapi tidak dapat diidentifikasikan dengan-Nya. Jika ada identifikasi ini, maka Allah menjadi benar-benar terlibat dalam sejarah, tetapi tidak demikian. Kenosis dari Putra di atas kayu Salib dan turunnya ke dalam neraka, keberjarakan antara Dia dan Bapa adalah mungkin karena kelahiran ini yangmendasarkan pengosongan diri yang pertama.

Prosesi kepada kelahiran (generasi) adalah kenosis pertama yang merangkul semua kenosis lainnya. Bapa melahirkan Putra yang benar-benar mengosongkan diri secara sempurna dan memberikan segalanya untuk Putra seperti tanpa henti memberikan dirisendiri dengan mengosongkan diri. Bapa tidak terbagi dan tidak memberikan apa-apa dari keilahian-Nya tetapi la mengosongkan diri memberikan segalanya untuk Putra. Dengan demikianPutra sungguh-sungguh Allah karena memiliki segalanya. Bapa mengkomunikasikan kepada Putra segala sesuatu yang Dia miliki. Dalam ketaatan-N ya,Putra memberikan kembali semuanya kepada Bapa. Dalam gerakan ini terjadi saling mengosongkan diri antara Bapa dan Putra serta disatukan dengan ikatan cinta yang adalah Pribadi Roh Kudus. Kelahiran dalam Allah merupakan peristiwa kenosis (pengosongan diri). Kenosis yang pertama ini merupakan dasaruntuk semua yang lain karenatanpa kenosis penciptaan tidak akan mungkin kalau bukan karena adakelahiran (generasi). Kita dapat berbicara tentang kenosis Allah dan Roh Kudus dalam Gereja, dalam sakramen-sakramen yanghidup di dalam kita. Visi Balthasar dikembangkan dari pengalaman mistik Adrienne von Speyr. 
"Allah (sebagai Bapa) dapat dengan cara ini memberikan keilahian-Nya, dan Allah (sebagai Putra) tidak menganggapnya semata-mata sebagai pinjaman tetapi memilikinya dalam "kesetaraan esensi", artinya "pemisahan" yang tidak terbayangkan dan tak tertandingi dari Tuhan, dari dirinya sendiri bahwa setiap pemisahan lain yang dimungkinkan (melalui itu), bahkan yang paling pahit dan tidak jelas, hanya dapat terjadi di dalamnya. [... " "Cinta kuat seperti neraka, tidak: lebih kuat, neraka menjadi mungkin hanya jika dipeluk oleh pembagian Bapa dan Putra yang mutlak dan nyata". 6

Dikatakan bahwa dalam kelahiran, Bapa memisahkan diri-Nya sendiri dan memberikan segalanya untuk Putra. Pemisahan inter-ilahi ini menemukan tempat pada tiap pemisahan lainnya, bahkan pemisahan orang berdosa dari Allah kembali kepada model yang sama. Para pendosa tidak berada di luar Allah sebab di luar Allah tidak ada suatupun. Jika Allah ada dan semua ada juga parapendosa merupakan pemisahan dari Allah. Ini berarti bahwa pemisahan harus menemukan kemungkinannya dari eksistensi di dalam Tuhan yakni dalam pemisahan kekal dari kelahiran (generasi). "Cinta kuat seperti neraka": ini merupakan ekspresi paradoks yang membuat kita berpikir tentang kemungkinan bahwa neraka akan dimenangkan, dipeluk oleh kasih Trinitas.O'Donnell menjelaskan visi dari von Balthasar dengan cara yang indah,

“Dari keabadian dan untuk keabadian Bapa telah menyerahkan diri-Nya kepada Putra, mempertaruhkan nyawa-N ya, milik-N ya untuk Putra, dan dari keabadian Putra menyatakan "Ya" kepada Bapa, dalam pengabdian yang sepenuhnya dan patuh kepada-N ya sehingga menyerahkan diri-Nya kepada Bapa menciptakan satu ruang untuk Putra. Bapa memisahkan diri dari diriNya sendiri, sehingga ada Putra. Pemisahan ini kemudian berkaitan dengan kekekalan Roh Kudus". [...] hal itu adalah pemenuhan dalam sejarah dari drama yang mendasar yang terjadi antara Bapa dan Putra, yang mempertaruhkan keberadaan mereka satu sama lain dari keabadian dan dengan demikian mereka berbeda tetapi masih satu dalam Roh Kudus yang merupakan ikatan persekutuan mereka."7

Kita telah berbicara tentang kenosis dalam konteks membuat ruang untuk ciptaan, untuk manusia, tetapi hal yang sama dalam arti tertentu dapat kita lihat di dalam Allah. Bapa memiliki kepenuhan dalam keilahian. Bapa adalah segalanya dan juga jika Bapa memiliki kepenuhan keilahian harus membuat sebuah ruang karena itu Putra juga bisa memiliki kepenuhan. Bapa mengosongkan diri membuat ruang untuk Putra, dan Putra memiliki kepenuhan keilahian. Jika ada tiga Pribadi dalamAllah yang satu dan masing-masing memiliki kepenuhan keilahian, hal itu berarti bahwa harus ada gerakan cinta yang terus-menerus.Seseorang

6 H.U. von Balthasar, Teodrammatica.vol iv, Jaca Book, 1986. pp. 302-303.

7 J. O'Donnell S, II M istero della Trinità. Editrice Pontificia Università Gregoriana Edizione Piemme, 1989, p. 67. 
perlu mengosongkan diri bagi yang lain untuk menciptakan ruang bagi yang lain. Kenosis kekal dari Roh Kudus: dalam relasi antara Putra dan Bapa tersembunyi, secara penuh di dalam fungsi dari Bapa dan Putra.

Segala sesuatu yang dibicarakan adalah peran dari hubungan antara Bapa dan Putra. Roh Kudus tampakya tidak melakukan apa yang menjadi peran-N ya. Roh Kudus seolah-olah tidak hadir. Dia tampak dalam hidup Inter-Tritunggal, tidak tampak sebagai pribadi(saya). Roh Kudus tampak sebagai KITA, dari Bapa dan Putra. Balthasar menegaskan bahwa kenosis dari kelahiran Putra sudah melampaui setiap drama yang mungkin antara Allah dan dunia karena setiap dunia dapat memiliki tempat hanya dari perbedaan antara Bapa dan Putra, terus terbuka dan diarahkan oleh Roh Kudus. Di dalam keberjarakan antara Bapa dan Putra ditemukan tempatuntuk dunia, karena tidak ada sesuatu di luar yang tidak ada. Rahner mengatakan bahwa jika dalam Perjanjian Baru inisiatif apapun adalah dari Bapa maka harus ditambahkan tampaknya bertentangan, semuanya mengalir dari kehidupan inter-Trinitas ini.

Cinta Tritunggal menjadi awal dari segala sesuatu. Sebagaimana telah kita sebutkan, bagi Balthasar kita dapat mengatakan sesuatu tentang kehidupan Tritunggal berangkat dari Trinitas ekonomi.Segala sesuatu yang terjadi, terjadi dalam kebebasan cinta. Tuhan tidak harus menciptakan dunia, tetapi secara paradoks hal itu ada sehingga dapat kita sebut kebutuhan bebas dari cinta. Cinta tidak dipaksa untuk memberi dirinya sendiri, tetapi karena cinta mengungkapkan cinta. Balthasar menolak retorika filsafat yang ingin melihat bahwa Allah sangat jauh dari penciptaan dan sejarah.

Ini menunjukkan bahwa di dalam Tuhan ditemukan kondisi dari kemungkinan drama di dunia. Balthasar kritis dalam berhadapan dengan tradisi Tomistik-Agustinus karena bagi dia belum bisadiungkapkan dengan baik hubungan timbal balik cinta dari pribadi ilahi. Pada kenyataannya tidaklah mudah berbicara tentang hubungan interTrinitaris seperti hubungan antara pribadi. Dalam skema klasik, Bapa melahirkan Putera dan bersama dengan Putera meniupkan Roh Kudus. Namun tidak tampak dengan baik yang Tiga saling mencintai secara timbal balik. Skema ini memungkinkan kita untuk memahami banyak hal, tetapi tidak mengungkapkan cinta timbal balik. Balthasar menunjukkan bahwa anugerah Putra ke dunia adalah suatu tindakan kasih kemudian juga kelahiran yang kekal yang harus dipahami sebagai suatu tindakan kasih dan bukan dijelaskan sebagai tindakan intelek. Di sini mengapa Balthasar lebih beralih kepada Bonaventura dengan model antar-pribadi walaupun ada batas-batas. Balthasar lebih memilih pendekatan Bonaventura bahwa menurutnya kelahiran Putra tercapai lewat M odum exemplaritatis dimana Bapa memberikan kodratnya sendiri untuk Putra yang menjadi gambar-N ya yang sempurna di dunia ini. Prosesi dari Roh 
Kudus terjadi per modum liberalitatis. Roh Kudus adalah sosok cinta yang sangat gembira dan meluap-luap. Tema terkait dengan pertanyaan kenosis dari Trinitas adalah bahwa itu pembalikan dari Trinitas ekonomi.

Pembalikan Trinitas ekonomi: pembalikan dalam peristiwa historis dari relasi Putra-Roh Kudus. Kita memiliki Bapa yang melahirkan Putra dan Roh Kudus yang dihasilkan. Jika dalam misteri inter-Trinitaris, Roh Kudus berasal/ dihasilkan dari Bapa dan Putra dan adalah ketiga di dalam taxis. Dalam sejarah keselamatan, Roh Kudus menjelma dalam hidup Putra, sehingga dapat dikatakan Bapa-Putra dan Roh Kudus. "Yang dihasilkan dalam diri-N ya adalah dari Roh Kudus": dalam ekonomi keselamatan, Putra mentaati, tetapi Roh tinggal pada-Nya. Roh Kudus memungkinkan ketaatan Putra kepada kehendak Bapa.

Kenosis menemukan solusinya dalam kebangkitan dan kenaikan. Von Balthasar tidak mengembangkan tema ini, tetapi kebangkitan juga memiliki satu struktur trinitaris. Von Balthasar mengatakan bahwa Bapa perlu menjadi inisiatordari kebangkitan.Putra tampak sebagai yang hidup yang bertindak dari diri-N ya sendiri dan Roh menjadi bebas bagi dunia.Balthasar berbicara tentang pembebasan paskah dari Roh melalui Putra dan Bapa. Roh dicurahkan oleh peristiwa kebangkitan, berarti tindakan obyektif dari Yesus dapat hidup dan dihayati oleh manusia. Dengan cara ini misteri Paskah diwujudkan melalui kita dan bagi kita. Menurut Balthasar kenosis Putra tidak berakhir dengan pemuliaan Paskah, bahkan setelah kenaikan, dalam Ekaristi yang bagi Balthasar adalah dimensi salib yang keluar. Putra dimuliakan, ditinggikan, kepada kita diutus Roh Kudus, tetapi kenosis cinta-Nya berlanjut dalam ekaristi.

\section{Trinitas dan G ereja}

Cinta abadi dari Trinitas datang dengan kuasa Roh dalam persekutuan dengan umat manusia melalui Gereja. Balthasar mengembangkan sebuah eklesiologi pengantin dan pneumatik. Ini berarti eklesiologi Tritunggal.Gereja adalah mempelai Kristus tetapi Roh Kudus menjamin persatuan dan perbedaan antara mempelai perempuan dan mempelai pria. Kristus dan Gereja tidak berada dalam kesatuan hipostatik tetapi mempelai perempuan dan mempelai pria adalah satu daging. Roh Kudus berperan di antara Kristus dan Gereja dan berperan secara analogi di antara Bapa dan Putra dalam hidup Tritunggal. Roh Kudus merupakan persatuan dari Bapa dan Putra dan pada saat yang sama Dia yang membedakan yang Pertama dan yang Kedua. Roh Kudus bersaksi atas kesatuan dan perbedaan dalam Gereja dan menekankan perbedaan orang percaya,seraya menyatukan mereka di dalam Kristus.

Gereja sebagai mempelai perempuan secara mendalam sangat feminin, karakter ini terlihat dalam Ekaristi di mana Gereja hanya bisa 
mengatakan "Ya" untuk apa yang mempelai pria lakukan. Penerimaan ini membutuhkan kesiapsediaan. Kita harus pasif, memiliki sikap menerima. Ini mengembangkan eklesiologi suami-istri dan eklesiologi pneumatik.Gereja sebagai mempelai perempuan adalah feminin dalam eksistensinya.Karakter ini ditunjukkan dalam Ekaristi di mana Gereja tidak melakukan apa-apa atas ini siatifnya sendiri. Kita tidak harus mengisi Gereja dengan penemuan kita. Hal kunci dalam Gereja dan bagi Gereja adalah tinggal dan mengikuti apa yang Kristus lakukan. O'Donnell menyajikan eklesiologi dari von Balthasar dengan mengatakan bahwa Gereja menunjukkan kekosongan kepada Bapa dan dipelihara oleh Roh Kudus. Tanpa karya Roh Kudus tidak mungkin ada Gereja Katolik.Roh Kudus mendampingi dan menyuburkannya. Seluruh misteri Gereja berada di bawah tindakan langsung dari Roh Kudus yang merupakan karunia dari Kristus yang bangkit.

Perjanjian Baru menunjukkan kepada kita bahwa Gereja menjadi hidup pada hari Pentakosta dimana Roh Kudus berdiam. Di antara orang percaya dan Roh Kudus ada hubungan timbal balik. Orang percaya tinggal di dalam Roh Kudus dan mereka menjadi orang percaya. Orangorang percaya yang tinggal di dalam Roh Kudus ini merupakan realitas yang paling intim dari ajaran Kristen. Roh Kudus memungkinkan kita memahami kedalaman akan kebenaran yang diwahyukan di dalam Yesus. Di dalam Roh terungkap peristiwa Yesus menjadi baru, hal ini yang merupakan kebaruan dari Perjanjian Baru. Roh Kudus menulis di dalam hati dan manusia mengenal Tuhan secara mendalam. Misi Roh Kudus di dalam Gereja bukan merupakan sebuah pewahyuan yang baru karena sudah penuh di dalam Yesus. Hal ini tidak berarti bahwa kepada kita telah dijelaskan secara lengkap. Roh Kudus memenuhi tugas-Nya di dalam ekonomi Trinitaris yang menjelaskan Sabda yang menjelma disalibkan dan dibangkitkan. Roh Kudus melakukannya dengan cara yang baru, selalu suatu kelahiran yang baru.

Roh Kudus tidak menyatakanhal-hal lain di luar Yesus sendiri. Roh Kudus menjelaskan segala sesuatu dari Sang Sabda, tetapi melakukannya dengan cara yang baru untuk kelahiran baru. Balthasar menekankan kebebasan Roh Kudus yang berkarya di dalam Gereja. Roh Kudus telah membentuk Gereja di dalam kesetiaan. Selama Gereja setia kepada Roh Kudus, dapat dipikirkan kembali, untuk beradaptasi dengan zaman baru. Misteri Kristus ada di dalam kebebasan Roh Kudus. Kesetiaan kepada tradisi dan kreativitas. Penting untuk menjaga keseimbangan di dalam dua hal ini yaitu setia kepada tradisi dengan kreativitas/ daya kreasi.

\section{Kebenaran Tritunggal}

Balthasar mengembangkan Teo-logika yang membahas tentang 
kebenaran Allah dan logos-Nya yang tak terbatas yang dapat mengekspresikan diri mereka untuk diwartakan dengan baik. Pendasaran biblis untuk Teo-logika adalah "A kulah Kebenaran" (Yoh 14:6). Balthasar yakin bahwa pertanyaan eksistensial-religius memiliki dimensi etis dan tidak dapat dipisahkan dari cinta yang merupakan anugerah sebagai sumber kebenaran. Seseorang dapat saja pintar sebagaimana setan tetapi tanpa cinta kita tidak dapat mengetahui realitas sampai akhir. Tanpa cinta kita memiliki kemampuan untuk memanipulasi realitas tetapi tidak mengetahuinya. Balthasar menyatakan bahwa eksistensi yang sama dari kebenaran abadi didasarkan atas cinta sehingga formulasi yang benar tanpa cinta bisa menjadi salah karena digunakan dengan cara yang salah.

Balthasar melihat kebenaran seperti sebuah keterlibatan dalam kasih Tritunggal. Kebenaran merupakan sebuah kebenaran Tritunggal. Balthasar mengacu pada kata-kata Yesus "Roh Kebenaran yang keluar dari Bapa, Ia akan bersaksi tentangAku" (Yoh 15:26). Balthasar menunjukkan bahwa jika Kristus adalah penafsir dari Bapa dan Roh Kudus adalah penafsir Putra. Roh Kudus membuat penafsiran dari penafsir, itu adalah satu-satunya kebenaran. Penjelasan dari Bapa melalui Putra, satu kebenaran Tritunggal. Sang Putra penerjemah dari kebenaran Bapa, dijelaskan oleh Roh Kudus yang memimpin kita kepada seluruh kebenaran. Penafsiran dari Bapa diberikan oleh Putra, dijelaskan oleh Roh Kudus dalam Gereja. Balthasar mengutip injil Yohanes: “Tetapi apabila la datang, yaitu Roh Kebenaran, Ia akan memimpin kamu ke dalam seluruh kebenaran; sebab Ia tidak akan berkata-kata dari diri-Nya sendiri, tetapi segala sesuatu yang didengar-Nya itulah yang akan dikatakan-Nya dan Ia akan memberitakan kepadamu hal-hal yang akan datang" (Yoh 16:13). Kita melihat dinamika kebenaran dari Tritunggal. Dalam bagian ini kita melihat bagaimana kebenaran Tritunggal disaksikan dan diwujudkan serta dimanifestasikan hingga sampai kepada kita begitu sangat dalam.

Tindakan Roh Kudus ini menjelaskan hubungan Putra yang sangat mendasar bagi Gereja. Perlu dicatat bahwa Balthasar tidak mengembangkan teologinya dengan cara mengakhiri sebuah risalah dan memulai yang lain. Dalam karya-karya Balthasar kita menemukan suatu pemikiran melingkar, kembali terus-menerus ke berbagai topik tetapi dari perspektif yang berbeda. Dal am Teo-logika kembali ke pertanyaan neraka sebagai peristiwa Tritunggal. Paragraf terakhir dari volume kedua disebut: Neraka dan Tritunggal. Balthasar mencatat bahwa refleksi atas neraka sebagai peristiwa Tritunggal, seperti refleksi lainnya (Teologi Sabtu suci),buah yang pasti dari teologinya.

Teologi Balthasar merupakan teologi Tritunggal. Dari awal sampai akhir penulis selalu mengacu pada misteri Tritunggal. Jika teologi Rahner adalah transendental (sebuah teologi yang berangkat dari struktur apriori 
dari subjektivitas manusia), teologi Balthasar adalah teologi transendental yang mengacu pada keindahan, kebaikan dan kebenaran yang menggambarkan Allah dalam sejarah keselamatan dalam perspektif transendental Tritunggal. Balthasar mengatakan bahwa sifat-sifat segala yang ada disebut transendental menjamin pendekatan yang paling sesuai untuk misteri Tritunggal. Sejak awal Balthasar ingin berbicara bentuk khas dari pewahyuan di dalam Yesus. Teologinya ingin berbicara tentang Diri yang terpancar di dalam keindahan, kebaikan dan kebenaran dari manifestasi dari Tuhan yang Tiga dan Satu. Beberapa orang mengatakan bahwa hal itu yang menyebabkan mengapa teologi dari Rahner atau teologiyang mulai dari sudut pandang antropologis yang paling cocok untuk dialog antaragama, sebaliknya teologi Balthasar akan lebih cocok untuk memperdalam pemahaman tentang iman di antara umat Katolik. Balthasar yakin bahwa metode yang paling efektif adalah mencari cara membuat orang yang tidak percaya melihat keindahan Yesus.

\section{Penutup}

Hans Urs von Balthasar mendasarkan seluruh teologinya kepada Tritunggal. Dia mengungkapkan relasi antar pribadi dalam hidup Tritunggal. Para pembaca diajak untuk menyadari cinta Tritunggal yang begitu luar biasa. A danya ciptaan dan penebusan bertitik tolak Tritunggal sendiri. Oleh karena itu segala sesuatu mengalir dari kekayaan Allah Tritunggal. Ada relasi kasih yang tiada hentinya pada tiga pribadi di dalam Tritunggal. Allah menyerahkan seluruhnya kepada Putera dan demikian juga Putera menyerahkan segalanya kepada Bapa. Demikian juga Roh Kudus yang berasal dari Allah mengosongkan diri yang memungkinkan relasi di dalam Tritunggal tanpa berhenti mengalirkan cinta. Ciptaan juga dimungkinkan karena adanya pengosongan diri di dalam Tritunggal dengan memberikan ruang bagi segala sesuatu yang bukan Allah. Dari kedalaman cinta Tritunggal itu teristimewa lewat peristiwa salib kita mengenal betapa besar cinta Yesus bagi manusia. Dan terlebih lagi misteri Sabtu Suci yang mengungkapkan solidaritas Allah bagi manusia. Yesus menemui para pendosa di neraka. Allah Tritunggal ingin menarik semua orang kepada keselamatan. Demikan juga halnya Gereja tidak lepas dari penyertaan Tritunggal sendiri. Roh Kudus yang dihembukan oleh Bapa dan Putera senantiasa membaharui dan menyertai Gereja. Mengimani Allah Tritunggal mencerminkan suatu iman yang hidup. Allah hidup di antara umat manusia. Cinta Allah sedemikan besar yang mengundang manusia bukan hanya mengaguminya tetapi untuk hidup dari kedalaman kasih Tritunggal itu sendiri.

* M arkus Situmorang

D osen Teologi STFT Widya Sasana M alang. Email: paxmarce@gmail.com 


\section{BIBLIOGRAFI}

Gallagher, M.P. M appe della fede, Dieci grandi esploratori cristiani.Milano: V\&P, 2011.

Kilby, K. Hans U rs von Balthasar on the Trinity, in The Trinity.ed. P.C. Phan, Cambridge:University Press 2011.

Tutto I'essere è amore, in $\mathrm{H}$ ans $\mathrm{U}$ rs von Balthasar. Figura e O pera. a cura di K. Lehmann e W. Kasper, Casale Monferrato, 1991.

O’Donnell, J.II M istero della Trinità. Roma:Editrice Pontificia Università Gregoriana Edizione Piemme. 1989.

Paradiso, M. La teologia trinitaria in Hans U rs von Balthasar. in http:// mondodomani.org/teologia/paradis02011.htm

Von Balthasar, H.U.Solo I'amore è credibile. Roma:Queriniana, 2001.

. Teodrammatica. III. Le persone del dramma. L'uomo in Cristo. Milano: Jaca Book, 1983.

. Teodrammatica. vol IV, Milano: Jaca Book, 1986. 